VOLUME 3 NO. 1

JUNE 2006

\title{
ISSN 1675-7017
}
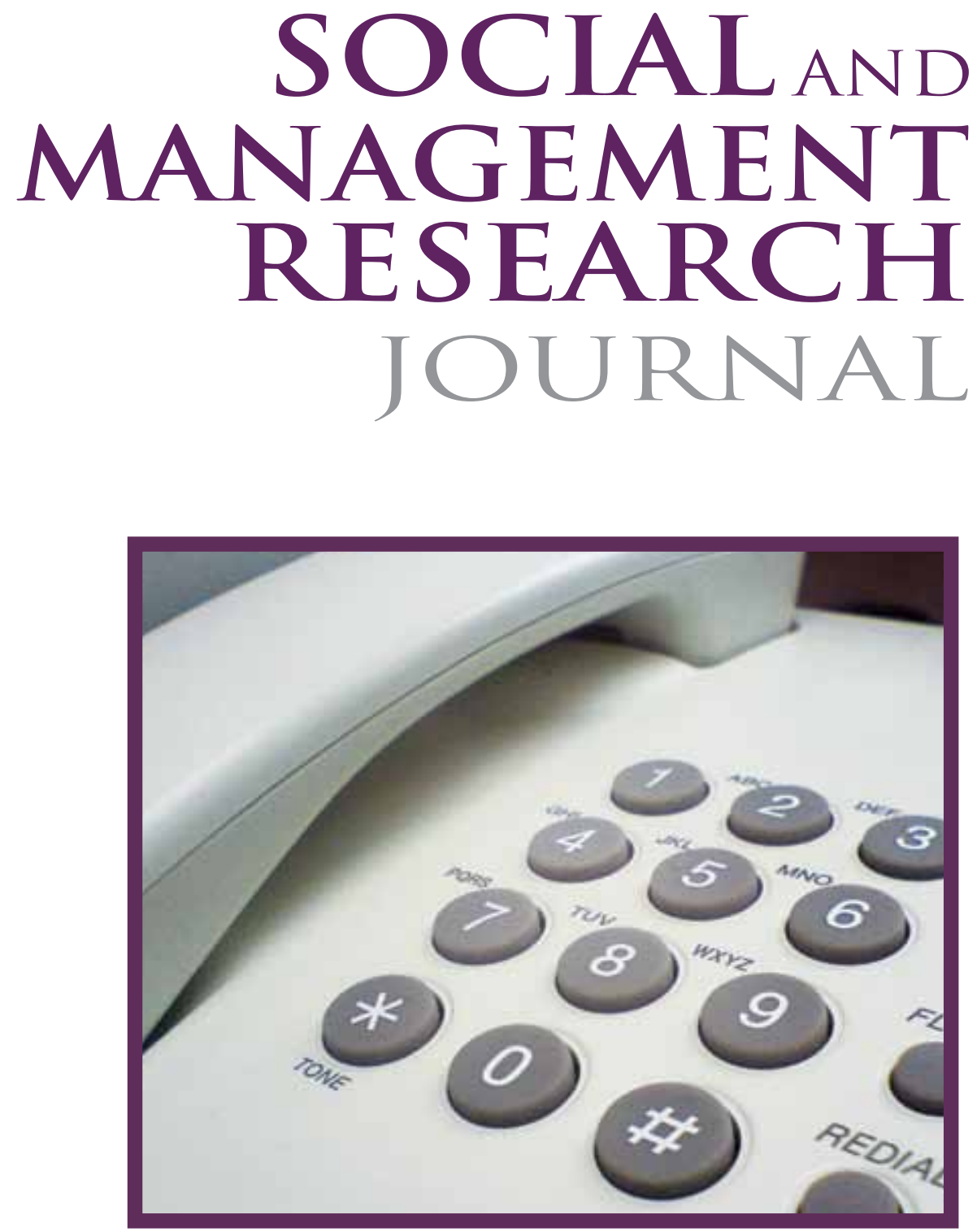

institute of Research, Development and Commercialisation 


\title{
SOCIAL AND MANAGEMENT RESEARCH JOURNAL
}

\author{
Chief Editor \\ Prof. Dr. Rashidah Abdul Rahman, \\ Universiti Teknologi MARA, Malaysia \\ Managing Editor \\ Assoc. Prof. Dr. Loo Ern Chen, \\ Universiti Teknologi MARA, Malaysia
}

\author{
Editorial Advisory and Review Board \\ Prof. Dr. Normah Omar, Universiti Teknologi MARA, Malaysia \\ Prof. Dr. Sardar M.N. Islam, Victoria University, Melbourne, Australia \\ Prof. Dr. Faridah Hassan, Universiti Teknologi MARA, Malaysia \\ Assistant Prof. Alexander N. Kostyuk, Ukrainian Academy of Banking of National \\ Bank of Ukraine, Sumy, Ukraine \\ Assoc. Prof. Dr. Razidah Ismail, Universiti Teknologi MARA, Malaysia \\ Assoc. Prof. Dr. Nor'azam Matstuki, Universiti Teknologi MARA, Malaysia \\ Assoc. Prof. Dr. Roshayani Arshad, Universiti Teknologi MARA, Malaysia \\ Assoc. Prof. Dr. Nor Aziah Alias, Universiti Teknologi MARA, Malaysia \\ Dr. Sabarinah Sheikh Ahmad, Universiti Teknologi MARA, Malaysia \\ Assoc. Prof. Dr. Maznah Wan Omar, Universiti Teknologi MARA, Malaysia \\ Dr. Megawati Omar, Universiti Teknologi MARA, Malaysia \\ Dr. Rashid Ameer, Universiti Teknologi MARA, Malaysia \\ Dr. Azizah Abdullah, Universiti Teknologi MARA, Malaysia \\ Dr. Azmi Abdul Hamid, Universiti Teknologi MARA, Malaysia \\ Dr. Kalsom Salleh, Universiti Teknologi MARA, Malaysia
}

Copyright (C) 2006 by Institute of Research, Development and Commercialisation (IRDC), Universiti Teknologi MARA, 40450 Shah Alam, Selangor, Malaysia.

All rights reserved. No part of this publication may be reproduced, stored in a retrieval system or transmitted in any form or by any means; electronics, mechanical, photocopying, recording or otherwise; without prior permission in writing from the Publisher.

Social and Management Research Journal is jointly published by Institute of Research, Development and Commercialisation (IRDC) and University Publication Centre (UPENA), Universiti Teknologi MARA, 40450 Shah Alam, Selangor, Malaysia.

The views and opinion expressed therein are those of the individual authors and the publication of these statements in the Scientific Research Journal do not imply endorsement by the publisher or the editorial staff. Copyright is vested in Universiti Teknologi MARA. Written permission is required to reproduce any part of this publication. 


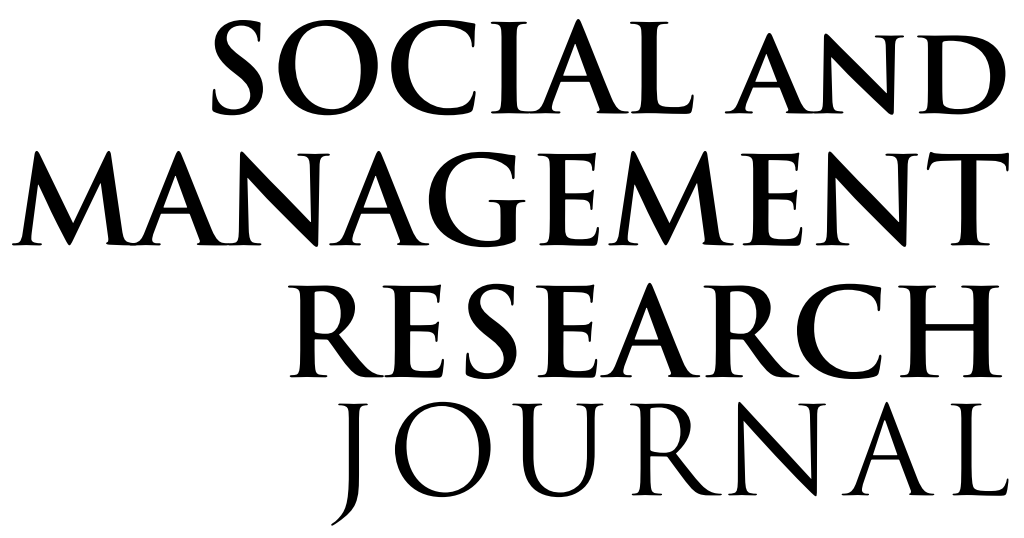

Vol. 3 No. 1

June 2006

ISSN 1675-7017

1. Trade Liberalization and Manufacturing Growth in Malaysia:

A Cointegration Analysis

Karunagaran Madhavan

Deviga Vengedasalam

Veera Pandiyan Kaliani Sundram

2. Using Text Mining Algorithm to Detect Gender Deception

Based on Malaysian Chat Room Lingo

Dianne L.M. Cheong

Nur Atiqah Sia Abdullah @ Sia Sze Yieng

3. The Impact of Cash Flows and Earnings on Dividend:

Evidence from Southeast Asia Countries

Khairul Anuar Kamardin

Mohd Shatari Abdul Ghafar

Wan Adibah Wan Ismail

4. Motivated Strategies for Learning Questionnaire (MSLQ): An

Empirical Analysis of the Value and Expectancy Theory

Wee Shu Hui

Maz Ainy Abdul Azis

Zarinah Abdul Rasit

5. The Structural and Functional Changes of Management Accountants

Aliza Ramli

Suzana Sulaiman 
6. Earnings Management and Sale of Assets

Nor'azam Mastuki

Nihlah Abdullah

7. Modelling Malaysian Road Accident Deaths: An Econometric Approach

Wan Fairos Wan Yaacob

Wan Zakiyatussariroh Wan Husin

8. Inter-relationship between Performance of Bursa Malaysia and Foreign Stock Markets

T. Chantrathevi P. Thuraisingam

Tew You Hoo

Dalila Daud

9. Predicting Corporate Financial Distress Using Logistic

Regression: Malaysian Evidence

Tew You Hoo

Enylina Nordin

10. Knowledge Management in Electronic Government: An

Exploratory Study of Local Authorities in Malaysia

Kalsom Salleh

Syed Noh Syed Ahmad 


\title{
Knowledge Management in Electronic Government: An Exploratory Study of Local Authorities in Malaysia
}

\author{
Kalsom Salleh \\ Syed Noh Syed Ahmad \\ Faculty of Accountancy, \\ Universiti Teknologi MARA (UiTM), Malaysia \\ Email: kalsom816@salam.uitm.edu.my,syed191@salam.uitm.edu.my
}

\begin{abstract}
Public sector organizations in developing countries have not received much attention in the research literature of Knowledge Management (KM). The potential impact of $K M$ in the public sector organizations affecting the stakeholders is greater compared to private sector organizations. This paper explores the role of KM in Local Authorities in the broader perspective towards achieving the Electronic Government (E-Government) orientation in Malaysia.

This research used a survey questionnaire distributed to all senior and middle management government officers in a multiple case study of three types of Local Authorities located in the Kuala Lumpur Federal Territory and the state of Selangor. These officers are responsible for strategic policies and operational management in various departments of the Local Authorities. The responses from the questionnaires will provide answers to two critical areas : awareness and readiness of KM adoption in terms of physical assets (KM technology) and intellectual assets (ICT skills and ICT trainings provided to management staff) and also the perceived opportunities and challenges in using KM as a strategic tool in developing knowledge - based civil service and the implementation of E-Government.
\end{abstract}

Keywords: Knowledge Management, Electronic Government, Public Sector Organization and Local Authorities

ISSN 1675-7017

(C) 2006 Universiti Teknologi MARA (UiTM), Malaysia. 


\section{Introduction}

For government organizations in Malaysia, the practice of knowledge management using people and technology to create Electronic Government (EGovernment) is important for the country to step into the knowledge - based economy era. Although knowledge management has been widely discussed by many academicians and practitioners there is little information on Knowledge Management (KM) as found in the public sector. Some examples of studies done in public organizations include: $\mathrm{KM}$ in a public organization of Malaysia (Syed-Ikhsan and Rowland, 2004), Benchmarking of KM in public organization of Malaysia (Syed-lkhsan and Rowland, 2004), knowledge sharing (Liebowitz and Chen, 2003), knowledge management initiatives (Shields, et al., 2000) and knowledge management in public administration (Wiig, K.M 2002).

Knowledge Management seeks to align knowledge processes with organizational objectives because improved decision making is an end goal of $\mathrm{KM}$. Therefore, technology, process, people and the organization structure and culture are the key enablers of the KM process. Apart from having effective KM strategies and adequate ICT infrastructure, the major difficulty facing organizations operating both in the private and public sector, today, is finding a way to overcome those softer cultural and behavioral obstacles that lie in the way of successful implementation of Knowledge Management. It was concluded by Ruggles (1998), Hackett (2000) and Taylor \& Wright (2004) that the main barriers to implement KM were all people - related issues such as poor understanding of what $\mathrm{KM}$ involved, a lack of top management leadership and a culture that inhibited knowledge sharing.

This research paper will examine the level of awareness and readiness of Malaysia's public organization in the adoption of knowledge management in the reinventing process for E-Government. Local Authority is used as a case study for this paper as it is an important component of the government machinery. The Local Authority is the third tier in the government system, which is at the forefront of public service delivery not only to individual citizen but also to other organizations of public and private sector. The adoption of $\mathrm{KM}$ in developing E-Government initiatives will be a catalyst to the national strategic policies to achieve the knowledge - based economy at the dawn of the $21^{\text {st }}$ century.

This research used a survey questionnaire distributed to all senior and middle management government officers of three types of Local Authorities located in the Kuala Lumpur Federal Territory and state of Selangor. The research paper will specifically focus on the level of awareness and preparedness of senior and middle management officers who are involved in the strategic and operational management function and decision making areas in Local Authorities which can enhance knowledge based products and services. The introduction of knowledge management initiatives towards E-government concept will also 
impose strains and challenges to equip government staff to become knowledge workers with the relevant ICT knowledge, skills and attitude in the new working context of knowledge based public sector.

Thus, this research attempts to study whether KM strategy in Local Authorities is a suitable platform/launching pad in achieving the E-Government initiatives.

\section{Problem Statement}

To date, there is no KM survey being carried out in Local Authorities (LA) in Malaysia. Therefore, this research paper aims to address the absence of this type of KM research by identifying the planned KM strategies to be adopted by the LA in the transformation process towards E-Government. This research paper will examine the level of awareness and readiness of Malaysia's Local Authorities in their adoption of knowledge management in the reinventing process for E-Government. The Local Authority is used as a research sample for this paper as it is an important component of the government machinery. The Local Authority is the third tier in the government system, which is at the forefront of public service delivery not only to individual citizen but also to other organizations of public and private sector. The adoption of successful implementation strategy of $K M$ as a suitable platform in developing EGovernment orientation will be a catalyst to the national strategic policies to achieve the knowledge - based economy at the dawn of the $21^{\text {st }}$ century.

\section{Objectives of Study}

The main objectives of this paper are as follows:

- To determine the level of awareness and readiness of $K M$ adoption in terms of physical assets and intellectual assets.

- To identify differences between big and small types of Local Authorities in the level of readiness for $\mathrm{KM}$ as a critical component of $\mathrm{E}$-Government evolution.

- To highlight critical issues that are seen as potential benefits and obstacles to the successful implementation of KM strategy as an important platform for E-Government evolution.

\section{Literature Review and Previous Research}

There are many definitions of Knowledge Management. In relation to this study, $\mathrm{KM}$ is defined as the process of capturing the collective expertise and 
intelligence in an organization and using them to foster innovation through continued learning organization (Nonaka, 1991, Quinn et al., 1996, Davenport, 1998). KM is also defined as the process of creating, capturing and using knowledge from an organization's intangible assets (knowledge workers) to enhance organizational performance (Public Service of Commission of Canada as quoted by Thomas b. Riley, 2002).

In terms of E-Government, it can be defined as the transformation of public sector internal and external relationship through Internet enabled operations and Information and Communication Technology to improve and optimize government service delivery, constituency participation and governance (KM Framework for Public Sector, paper presented by Dr Hamzah Kassim for Conference CIO 2003, 21 - 22 August 2003). In addition, Lieber (2000) defines EGovernment as implementing cost effective models for citizens, industry, federal employees and other stakeholders to conduct business transactions online. This concept integrates strategy, process, organization and technology.

There are several studies done in public sector organizations concerning knowledge sharing (Liebowitz and Chen, 2003), KM initiatives (Shields et al., 2000), knowledge management practices, particularly in decision making and situation handling (Wig, 2002), and KM in a public organization in Malaysia (Syed-Ikhsan, S.O.S and Rowland, F. 2004). Syed-lkhsan and Rowland (2004) conducted an in-depth empirical case study on Ministry of Entrepreneur Development of Malaysia from organization perspective to study on the relationship between organizational elements such as organizational culture and structure, technology, people/human resource, political directives and the performance of knowledge transfer. Data was gathered through questionnaires distributed to 204 respondents from Grade One to Grade Six in the headquarters and both the regional and state offices during the period from September to December 2001. A total of 154 questionnaires (75.5\%) were returned and analysed. The study revealed that the Ministry currently does not have any specific KM strategy. However, the study showed that knowledge in the Ministry was available and embedded in the Ministry's procedures and policies, job manual procedures, ISO 9002, desk file, work flow and database. The study has also revealed a variety of potent relationship between knowledge assets and organizational elements with knowledge transfer performance. Technology may not be able to stimulate the flow of knowledge without attention given to the other organizational elements for the successful KM strategy. Although technology plays an important role in developing and sharing knowledge, without the attention to the cultural and organizational context in which people are encouraged to share their knowledge, technology may not be able to stimulate the flow of knowledge. Therefore all organizational elements organizational culture, organizational structure, technology and people/human resource should always be considered together. In addition, public organizations 
should never neglect issues on political directives when implementing knowledge management.

Technologies are only the knowledge enabler and technology implementation cannot in itself provide a solution. The success of a Knowledge Management strategy depends on the support and participation of employees to generate, capture, share, learn and apply knowledge. Technology can facilitate $\mathrm{KM}$ processes but if employees do not buy-in and contribute to them, its implementation will not enable organization to fully utilize is intellectual assets (Dr Hamzah Kassim, CEO, Innovation Associates Sdn Bhd, KM Framework for Public Sector, CIO conference 2003, Putrajaya Marriot, Malaysia, 21-22 August 2003).

\section{Research Methodology}

\section{Development and Administration of the Questionnaire}

The questionnaire were developed based on various research studies on KM in public sector and private sector organizations such as those carried out by Syed-Ikhsan and Rowland (2004), Sattar Bawany (2004) and Ahmad Al-Athari and Mohamed Zairi (2001). These survey instruments were tested by carrying out a pilot study. The pilot study involved conducting interviews with a few senior and middle management officers in three local authorities in the Kuala Lumpur Federal Territory and Selangor State as well as obtaining their instant replies from the completed questionnaire.

Based on the feedback from the pilot study, a final version of the questionnaire was prepared. The questionnaire was prepared in two languages (English and Malay) and contained three parts. Part 1 consists of profile of respondents, Part 2 consists of questions regarding IT equipment and ICT infrastructure and Part 3 consists of statements where respondents were asked to indicate their perceptions relating to their awareness of $\mathrm{KM}, \mathrm{KM}$ technology, opportunities and challenges in using ICT as a strategic tool in developing and adopting KM. The survey was conducted for two months starting on 23 March 2005 and ending on 23 May 2005. A total of 411 questionnaires were distributed and 163 completed questionnaires (40\%) were returned. Three (3) questionnaires were not analysed as the respondents did not answer fully the important parts of questionnaires. The details concerning the questionnaires analysed are given in Table 1 below. 
Table 1: Distribution and Collection of Questionnaires

\begin{tabular}{cccc}
\hline $\begin{array}{c}\text { Types of Local Authorities } \\
\text { (LA) }\end{array}$ & $\begin{array}{c}\text { Number of } \\
\text { LA }\end{array}$ & $\begin{array}{c}\text { Number of } \\
\text { Questionnaires } \\
\text { Distributed }\end{array}$ & $\begin{array}{c}\text { Number of } \\
\text { Questionnaires } \\
\text { Returned and Analyses }\end{array}$ \\
\hline City Councils & 2 & 148 & $43(27 \%)$ \\
Municipal Councils & 6 & 195 & $91(57 \%)$ \\
District Councils & 5 & 68 & $26(16 \%)$ \\
\hline Total & 13 & 411 & $160(39 \%)$ \\
\hline
\end{tabular}

\section{Reliability Analysis}

A reliability test was carried out on those behavioral questions in part 2 and part 3 of the piloted and pre-test questionnaire. The Cronbach's coefficient alpha fell in the range of between 0.80 to 0.98 which are considered as good indicators to test the consistency of respondents' answer to all the items and scales used in the measurement. As the response rate was about $40 \%$, it was decided to perform a non-response bias test. This is to minimize the possibility that the results obtained from this survey will not be affected by the nonrespondents. This test consists of comparing the answers of the early and late replies of the respondents. A non-parametric procedure (Mann-Whitney $U$ test) was used to compare the mean rankings of the answers in Part 2 and Part 3 . The test results showed that there were no statistical differences in $95 \%$ of the variables of the questionnaires. Thus, we concluded that problems arising from non-response bias are minimal.

\section{Results and Discussions}

\section{Profile of Respondents}

There was a fairly good mixed of respondents from the various categories of senior and middle management officers working in different types of departments in the three different types of local authorities.

Table 2 shows the spread of responses between three types of Local Authorities and between two categories of management staff. Mayor of city councils heads of municipal and district councils and directors and deputy directors of local authorities are categorized as senior management. Middle management are those officers in professional and administrative positions such as accountants, engineers, architects, medical doctors, lawyers, administrators and others who are responsible for strategic policies and decision making purposes of different types of departments in their respective local 
Table 2: Types of Local Authorities (LA) \& Respondents' Profile

\begin{tabular}{ccccc}
\hline Types of LA & No. of LA & Respondents & $\begin{array}{c}\text { Senior } \\
\text { Management }\end{array}$ & $\begin{array}{c}\text { Middle } \\
\text { Management }\end{array}$ \\
\hline City Councils & 2 & $43(27 \%)$ & $7(16 \%)$ & $36(84 \%)$ \\
Municipal Councils & 6 & $91(57 \%)$ & $17(19 \%)$ & $74(81 \%)$ \\
District Councils & 5 & $26(16 \%)$ & $2(8 \%)$ & $24(92 \%)$ \\
\hline Total & 13 & 160 & $16(16 \%)$ & $134(84 \%)$ \\
\hline
\end{tabular}

authorities. The demographic profiles of the 160 senior and middle management officers are presented below in Table 3.

Respondents to the questionnaires made up $16 \%$ of senior management and $84 \%$ from middle management. In terms of age, $37 \%$ of the respondents are above 40 years and $63 \%$ below 40 years. More than half $(66 \%)$ of respondents have less than 10 years of working experience. Interestingly, 13\% of the respondents have more than 20 years working experience, $29 \%$ of them are senior level of management and $71 \%$ represents the professional and administrative officers. As can be seen from the above table, the respondents who answered the questionnaires were those with extensive working experiences and those holding responsible positions in the various departments of the three types of Local Authorities. Their answers to the questionnaires give a high level of credibility in terms of their opinions regarding the issues raised in the questionnaires.

Table 3: Demographic Profile - Senior and Middle Management Officers of Local Authorities

\begin{tabular}{ccccc}
\hline Description & Senior Mgt & Middle Mgt & Total & Average \\
\hline Age: & & & & \\
above 51 years & $9(56 \%)$ & $7(44 \%)$ & $16(10 \%)$ & Mean $=38$ \\
$41-50$ & $13(30 \%)$ & $30(70 \%)$ & $43(27 \%)$ & Median $=37$ \\
$31-40$ & $1(2 \%)$ & $55(98 \%)$ & $56(35 \%)$ & Mode $=30$ \\
$25-30$ & $2(5 \%)$ & $39(95 \%)$ & $41(26 \%)$ & $\mathrm{N}=163$ \\
below 25 years & $1(25 \%)$ & $3(75 \%)$ & $4(2 \%)$ & \\
& $26(16 \%)$ & $134(84 \%)$ & 160 & \\
Work Experience: & & & & \\
$21-40$ & $6(29 \%)$ & $15(71 \%)$ & $21(13 \%)$ & Mean $=10$ \\
$11-20$ & $4(12 \%)$ & $29(88 \%)$ & $33(21 \%)$ & Median $=7$ \\
$6-10$ & $5(13 \%)$ & $33(87 \%)$ & $38(24 \%)$ & Mode $=4$ \\
below 5 years & $11(16 \%)$ & $57(84 \%)$ & $68(42 \%)$ & N = 160 \\
& $26(16 \%)$ & $134(84 \%)$ & 160 & \\
\hline
\end{tabular}




\section{ICT Skills and Training of Senior and Middle Management Officers}

Table 4 A represents the cross tabulation of ICT skills and training of the respondents. The cross tabulation shows the salient features of the development of intellectual assets (human capital) of local authorities in terms of ICT skills and training.

Table 4 A: ICT Skills and Trainings of Respondents

\begin{tabular}{|c|c|c|c|}
\hline Description & Senior Mgt. & Middle Mgt. & Total \\
\hline $\begin{array}{l}\text { Basic ICT Training: } N=160 \\
\text { - Attended } \\
\text { - Did not attend }\end{array}$ & $\begin{array}{l}16(62 \%) \\
10(38 \%) \\
26\end{array}$ & $\begin{array}{l}80(60 \%) \\
54(40 \%) \\
134\end{array}$ & $\begin{array}{c}96(60 \%) \\
64(40 \%) \\
160\end{array}$ \\
\hline $\begin{array}{l}\text { Advance ICT Training: } N=160 \\
\text { - Attended } \\
\text { - Did not attend }\end{array}$ & $\begin{array}{c}7(27 \%) \\
19(73 \%) \\
26\end{array}$ & $\begin{array}{c}36(27 \%) \\
98(73 \%) \\
\quad 134\end{array}$ & $\begin{array}{c}43(27 \%) \\
117(73 \%) \\
160\end{array}$ \\
\hline $\begin{array}{l}\text { Use of Computer Per Day } \\
\text { - } 1-3 \text { hours per day } \\
\text { - } 4-6 \text { hours per day } \\
->7 \text { hours per day } \\
N=160\end{array}$ & $\begin{array}{l}18(69 \%) \\
7(27 \%) \\
1(4 \%) \\
26(16 \%)\end{array}$ & $\begin{array}{c}73(54 \%) \\
53(40 \%) \\
8(6 \%) \\
134(84 \%)\end{array}$ & $\begin{array}{c}91(57 \%) \\
60(38 \%) \\
9(5 \%) \\
160\end{array}$ \\
\hline
\end{tabular}

The percentage of senior and middle management officers who had attended basic ICT training is $60 \%$. The percentage of senior management who attended basic ICT training is $62 \%$, which is slightly higher than middle management officer (60\%). However, in terms of advance ICT skills and training, the percentage of senior and middle management staff who had attended such training is 43 people only (27\%). Almost the same percentage, $27 \%$ indicated that both senior and middle management officers had attended advanced ICT training. The findings also revealed that apart from formal ICT training, many respondents acquired the basic ICT skills such as word processing, presentation software, internet access, email and spreadsheet applications through selflearning process.

In terms of computer usage, $57 \%$ of total respondents indicated that they used the computers within 1-3 hours per day and another $38 \%$ of respondents use the computers between 4-6 hours per day and $5 \%$ of respondents used more than 7 hours per day. A check on the profile of those who used the computer for more than 7 hours a day showed that they were accountants, IT managers and administrative officers. 
Table 4 B: Supply of IT Equipments to Respondents of Local Authorities

\begin{tabular}{lccc}
\hline Description & Senior Mgt. & Middle Mgt. & Total \\
\hline Supply of IT Equipments & & & \\
- Desktop/Note Book/PDA & $5(19 \%)$ & $4(3 \%)$ & $9(6 \%)$ \\
- Desktop/Note Book & $11(42 \%)$ & $42(31 \%)$ & $53(33 \%)$ \\
- Note Book & $2(8 \%)$ & $6(5 \%)$ & $8(5 \%)$ \\
- Desktop & $8(31 \%)$ & $82(61 \%)$ & $90(56 \%)$ \\
N $=160$ & $26(16 \%)$ & $134(84 \%)$ & 160 \\
\hline
\end{tabular}

It is not surprising to note that $19 \%$ of senior management officers were supplied with desktop (PC), note book and personal digital assistance (PDA) as compared to only $3 \%$ for the middle management. The Table $4 \mathrm{~B}$ seems to indicate that officers belonging to the senior management were better equipped with IT equipment. In the case of the supply of desktop and note book to the officers of local authorities, $42 \%$ of senior management and $31 \%$ middle management officers were supplied with both types of equipment. In the case of officers supplied with only a computer, $31 \%$ were senior management and $61 \%$ are middle management officers. It is important to note that all of the respondents had been supplied with at least one piece of IT equipment.

\section{Perceptions on the Importance of Communication Channels}

Table 5 A: Traditional Mode of Communication Channels and Information Flows

\begin{tabular}{lccccc}
\hline Types of Communication Channels & \multicolumn{5}{c}{ Perceived Importance } \\
\cline { 2 - 6 } & $\mathrm{N}$ & Mean & $\begin{array}{c}\text { Std. } \\
\text { Dev }\end{array}$ & $\begin{array}{c}\text { Chi- } \\
\text { Square }\end{array}$ & $\begin{array}{c}\text { Asymp } \\
\text {.sig }\end{array}$ \\
\hline 1 Face to face (meetings, forums, & 160 & 4.58 & .685 & 3.641 & 0.162 \\
$\quad \begin{array}{l}\text { workshops) } \\
\text { Paper Documentation (circulars, }\end{array}$ & 160 & 4.52 & .652 & 1.574 & 0.455 \\
$\begin{array}{l}\text { letters, internal memorandum } \\
3 \text { Notice Board for Announcement }\end{array}$ & 160 & 4.20 & .835 & 2.528 & 0.283 \\
4 Public Address System & 152 & 4.13 & .897 & 1.698 & 0.428 \\
5 Internal journal/newsletters & 149 & 3.62 & .941 & 0.368 & 0.832 \\
\hline
\end{tabular}

- Likert scale ranging from ' 1 ' which means not important at all to ' 5 ' which represents very important 
Table 5 B: Electronic Mode of Communication Channels and Information Flows

\begin{tabular}{lccccc}
\hline Types of Communication Channels & \multicolumn{5}{c}{ Perceived Importance* } \\
\cline { 2 - 6 } & $\mathrm{N}$ & Mean & $\begin{array}{c}\text { Std. } \\
\text { Dev. }\end{array}$ & $\begin{array}{c}\text { Chi- } \\
\text { Square }\end{array}$ & $\begin{array}{c}\text { Asymp } \\
\text {.sig }\end{array}$ \\
\hline & 156 & 4.39 & .658 & 2.702 & 0.259 \\
\hline 1. Internet access & 159 & 4.34 & .841 & 12.841 & $0.002+$ \\
2. Email * & 156 & 4.26 & .834 & 0.660 & 0.719 \\
3. Intranet & 142 & 3.98 & .854 & 2.437 & 0.296 \\
$\begin{array}{l}\text { 4. Staff Portal } \\
\text { 5. Any specific decision-support } \\
\text { system e.g. Interactive database } \\
\text { (data warehouse) }\end{array}$ & 141 & 3.98 & .890 & 2.006 & 0.367 \\
$\begin{array}{l}\text { 6. Groupware to support } \\
\text { collaborative platform c.g. lotus } \\
\text { note * }\end{array}$ & 144 & 3.97 & 0.956 & 12.817 & $0.002+$ \\
$\begin{array}{l}\text { 7. Professional discussion groups } \\
\text { e.g. web-based forum / } \\
\text { video-conferencing * }\end{array}$ & 140 & 3.93 & .854 & 5.856 & $0.053+$ \\
8. Electronic Notice Board & 143 & 3.92 & .986 & 0.449 & 0.799 \\
9. SMS & 150 & 3.81 & 1.006 & 2.277 & 0.320 \\
\hline
\end{tabular}

* Likert scale ranging from ' 1 ' which means not important at all to ' 5 ' which represents very important

- Variable with significant differences between groups ( 3 types of Local Authorities) as tested using Kruskali - Wallis test at $5 \%$ level of significance+.

Table $5 \mathrm{~A}$ and $5 \mathrm{~B}$ show the ranking score by the respondents of their perceived importance in relation to the technology infrastructure in terms of communication channels. Communication channels are important aspects of Knowledge Management as it indicated how explicit knowledge (e.g.: knowledge embedded in procedures and policies, desk file, database) and tacit knowledge (e.g.: personal experience, know how, insights) were transferred and shared within and outside the organization.

Table $5 \mathrm{~A}$ shows that the respondents perceived that the traditional mode of communication channels such as face to face meetings, paper documentation, notice board and the public address system as important (mean score of $>4.00$ ). However, internal journal or newsletter are perceived as of moderately important) mean score 3.62). Kruskali - Wallis test was conducted between the three types of Local Authorities regarding their perceived importance of these traditional channels of communication. The tests indicated there are no significant differences at the $5 \%$ level of significance. It could be concluded that there is a consensus among the Local Authorities as to their perceived importance of the 
traditional mode of communication channels within and between other departments.

Table $5 \mathrm{~B}$ shows that respondents from all the three types of Local authorities have ranked the mean score of more than 4.00 to internet access, email and intranet which they perceived as important for electronic mode of communication channels. Kruskall - Wallis test was conducted between the three types of Local Authorities regarding their perceived importance of these electronic modes of communication channels. The tests indicated there are significant differences in the ranking of importance by the three types of local authorities. The city councils gave the lowest mean ranking for the importance of email, groupware and professional forums via web based forum or videoconference among the three types of local authorities. This is an unexpected result because the application of electronic means of communication channels is more relevant given the size of city councils and Anecdotal evidence based on the pilot testing phase suggests that although electronic communication channels are available, they are seldom used as a means of communication for knowledge transfer and knowledge sharing between the senior and middle management officers.

\section{Perceptions of the Importance of Knowledge Management}

All the respondents gave high rankings of the benefits of knowledge management as given in Table 6 below. The high mean scores indicate that there is a realization among the local authorities in respect to the important role of knowledge management in facilitating knowledge transfer and knowledge sharing activities. Kruskall - Wallis tests indicate that two variables show significant difference in the mean ranking among the local authorities: variables relating to improved efficiency of people and operations and increased responsiveness to customers' needs. The mean ranking of city councils and municipal councils were significantly higher than that of district councils.

\section{Perceptions of the Obstacles to Implementation of KM}

The respondents were asked to rate the obstacles for the successful implementation of Information Communication and Technology (ICT) infrastructure as a platform for knowledge management (KM) in their organization on 24 items as shown in Table 7 below: 
Table 6: Perceived Importance of Knowledge Management

\begin{tabular}{|c|c|c|c|c|c|}
\hline \multirow[t]{2}{*}{ Benefits of Knowledge Management } & \multicolumn{5}{|c|}{ Perceived Importance* } \\
\hline & $\mathrm{N}$ & Mean & $\begin{array}{l}\text { Std. } \\
\text { Dev. }\end{array}$ & $\begin{array}{l}\text { Chi- } \\
\text { Square }\end{array}$ & $\begin{array}{l}\text { Asymp } \\
\text {.sig }\end{array}$ \\
\hline 1. Teamwork & 160 & 4.65 & .584 & 1.717 & 0.424 \\
\hline $\begin{array}{l}\text { 2. Using knowledge in decision } \\
\text { making }\end{array}$ & 160 & 4.54 & .591 & 0.694 & 0.707 \\
\hline $\begin{array}{l}\text { 3. Improved efficiency of people } \\
\text { and operations }\end{array}$ & 159 & 4.53 & .604 & 5.971 & $0.051+$ \\
\hline 4. Higher staff productivity & 156 & 4.49 & 677 & 2.725 & 0.256 \\
\hline 5. Improved products/services & 159 & 4.48 & .664 & 4.925 & 0.085 \\
\hline $\begin{array}{l}\text { 6. Increased responsiveness to } \\
\text { customers' needs }\end{array}$ & 159 & 4.45 & .662 & 6.735 & $0.034+$ \\
\hline 7. More innovation/creativity & 159 & 4.45 & .643 & 4.920 & 0.085 \\
\hline $\begin{array}{l}\text { 8. Quick response to other } \\
\text { organizations' needs }\end{array}$ & 159 & 4.44 & .671 & 2.076 & 0.354 \\
\hline 9. Employee learning & 160 & 4.43 & .609 & 0.145 & 0.930 \\
\hline 10. Generating new knowledge & 160 & 4.40 & .645 & 0.032 & 0.984 \\
\hline $\begin{array}{l}\text { 11. Creating training system based } \\
\text { on new knowledge }\end{array}$ & 158 & 4.40 & .638 & 1.002 & 0.606 \\
\hline 12. Sharing best practice & 158 & 4.37 & .671 & 2.143 & 0.343 \\
\hline $\begin{array}{l}\text { 13. Embedding new knowledge in } \\
\text { the organization }\end{array}$ & 160 & 4.36 & .674 & 0.056 & 0.972 \\
\hline 14. Creating knowledge databases & 160 & 4.35 & .682 & 1.687 & 0.430 \\
\hline 15. Cost savings & 155 & 4.32 & .755 & 4.475 & 0.107 \\
\hline 16. Accessing external knowledge & 160 & 4.31 & .664 & 2.382 & 0.304 \\
\hline $\begin{array}{l}\text { 17. Transferring existing knowledge } \\
\text { to other parts of the organization }\end{array}$ & 160 & 4.25 & .789 & 0.104 & 0.949 \\
\hline $\begin{array}{l}\text { 18. Measuring the value of } \\
\text { knowledge assets obtained from } \\
\text { employees }\end{array}$ & 159 & 4.13 & .704 & 0.419 & 0.811 \\
\hline $\begin{array}{l}\text { 19. Facilitating knowledge growth } \\
\text { through culture and incentives }\end{array}$ & 160 & 4.11 & .750 & 2.864 & 0.239 \\
\hline
\end{tabular}

* Likert scale ranging from ' 1 ' which means not important at all to ' 5 ' which represents very important.

- Variables with significant differences between groups (3 types of Local Authorities) as tested using Kruskall - Walls test at $5 \%$ level of significance+. 
Table 7: Obstacles to Successful Implementation of ICT as an Important Platform For KM

\begin{tabular}{|c|c|c|c|c|c|}
\hline \multirow{2}{*}{$\begin{array}{l}\text { Perceived Obstacles of } \mathrm{KM} \\
\text { Implementation }\end{array}$} & \multicolumn{5}{|c|}{ Level of Agreement* } \\
\hline & $\mathrm{N}$ & Mean & $\begin{array}{l}\text { Std. } \\
\text { Dev. }\end{array}$ & $\begin{array}{l}\text { Chi- } \\
\text { Square }\end{array}$ & $\begin{array}{l}\text { Asymp } \\
\text {.sig }\end{array}$ \\
\hline $\begin{array}{l}\text { 1. Difficulties of changing } \\
\text { employees' behaviour and } \\
\text { attitude* }\end{array}$ & 160 & 4.25 & .876 & 7.798 & $0.020+$ \\
\hline $\begin{array}{l}\text { 2. Existing workload is heavy } \\
\text { and thus lack of time to spend } \\
\text { on KM initiatives* }\end{array}$ & 160 & 4.04 & .977 & 6.944 & $0.031+$ \\
\hline $\begin{array}{l}\text { 3. Organizational culture - lack } \\
\text { of knowledge sharing and trust }\end{array}$ & 160 & 4.00 & .933 & 2.514 & 0.284 \\
\hline $\begin{array}{l}\text { 4. Concerns regarding } \\
\text { confidentiality of information } \\
\text { transmitted and received by } \\
\text { emailing }\end{array}$ & 160 & 3.98 & .984 & 3.101 & 0.212 \\
\hline $\begin{array}{l}\text { 5. Lack of incentive system - } \\
\text { no reward and recognition for } \\
\text { performance improvement and } \\
\text { knowledge sharing }\end{array}$ & 160 & 3.96 & .951 & 4.409 & 0.110 \\
\hline $\begin{array}{l}\text { 6. Lack of well - trained staff \& } \\
\text { expertise }\end{array}$ & 160 & 3.88 & 1.002 & 4.886 & 0.087 \\
\hline $\begin{array}{l}\text { 7. Concerns over security of } \\
\text { information and obsolete } \\
\text { information stored in electronic } \\
\text { databases }\end{array}$ & 160 & 3.88 & 1.014 & 1.180 & 0.554 \\
\hline $\begin{array}{l}\text { 8. Letters are seen as providing } \\
\text { evidence as opposed to c-mails }\end{array}$ & 160 & 3.86 & 1.000 & 0.740 & 0.691 \\
\hline $\begin{array}{l}\text { 9. Attitude that implementation } \\
\text { of } \mathrm{KM} \text { is not an urgent matter }\end{array}$ & 160 & 3.79 & 1.060 & 4.060 & 0.131 \\
\hline $\begin{array}{l}\text { 10. Policies, procedures and } \\
\text { routines are paper based }\end{array}$ & 160 & 3.77 & .994 & 4.877 & 0.087 \\
\hline $\begin{array}{l}\text { 11. Difficultics of updating ICT \& } \\
\text { KM technology }\end{array}$ & 160 & 3.75 & 1.053 & 3.705 & 0.157 \\
\hline $\begin{array}{l}\text { 12. Inadequate training, seminars } \\
\& \text { workshops on ICT \& KM } \\
\text { technology* }\end{array}$ & 160 & 3.72 & 1.119 & 7.083 & $0.029+$ \\
\hline $\begin{array}{l}\text { 13. Organization hierarchy } \\
\text { (accountability, communication } \\
\text { channels \& command and } \\
\text { control procedures)* }\end{array}$ & 160 & 3.71 & 1.027 & 5.752 & $0.056+$ \\
\hline
\end{tabular}


Table 7 - continued

\begin{tabular}{|c|c|c|c|c|c|}
\hline $\begin{array}{l}\text { 14. Top management commitments } \\
\& \text { leadership* }\end{array}$ & 160 & 3.67 & 1.158 & 7.185 & $0.028+$ \\
\hline 15. Lack of awareness on $\mathrm{KM}$ & 157 & 3.67 & 1.071 & 3.513 & 0.173 \\
\hline \multicolumn{6}{|l|}{ 16. Supporting staff } \\
\hline $\begin{array}{l}\text { 17. Lack of financial resources to } \\
\text { support } \mathrm{KM}^{*}\end{array}$ & 160 & 3.63 & 1.242 & 24.674 & $0.000+$ \\
\hline $\begin{array}{l}\text { 18. Inadequacy of ICT } \\
\text { infrastructure \& } \mathrm{KM} \text { tools* }\end{array}$ & 160 & 3.60 & 1.169 & 9.416 & $0.009+$ \\
\hline $\begin{array}{l}\text { 19. Emphasis on individual rather } \\
\text { than teamwork }\end{array}$ & 160 & 3.59 & 1.107 & 0.517 & 0.772 \\
\hline $\begin{array}{l}\text { 20. No documentation of policies, } \\
\text { procedures and operating rules } \\
\text { for the KM implementation } \\
\text { processes* }\end{array}$ & 160 & 3.56 & 1.163 & 6.743 & $0.034+$ \\
\hline $\begin{array}{l}\text { 21. Non-standardised processes } \& \\
\text { procedures* }\end{array}$ & 156 & 3.53 & 1.183 & 9.999 & $0.007+$ \\
\hline \multicolumn{6}{|l|}{ 22. Lack of awareness on $\mathrm{KM}$} \\
\hline 23. Top management* & 160 & 3.47 & 1.217 & 13.261 & $0.001+$ \\
\hline 24. Middle management* & 156 & 3.46 & 1.132 & 6.545 & $0.038+$ \\
\hline 25. Political interference* & 158 & 3.41 & 1.257 & 14.221 & $0.001+$ \\
\hline $\begin{array}{l}\text { 26. Communication channels using } \\
\text { ICT \& KM technology e.g. } \\
\text { e-mail are seemed to be less } \\
\text { effective than traditional } \\
\text { methods e.g. letters }\end{array}$ & 160 & 3.23 & 1.208 & 1.094 & 0.579 \\
\hline
\end{tabular}

* Likert scale ranging from ' $I$ ' which means strongly disagree to ' 5 ' which represents strongly agree

- Variables with significant differences between groups (3 types of Local Authorities) as tested using Kruskall - Wallis test at $5 \%$ level of significance.

The respondents gave high mean scores of more than 4.00 for there variables that are difficulties of changing employees' behavior and attitude, existing workload is heavy and thus lack of time to spend on KM initiatives and organizational culture - lack of knowledge sharing and trust. Kruskall - Wallis rank test shows that out of 24 items, 12 items $(50 \%)$ show significant differences among the three types of Local Authorities. In all the 12 variables that show significant differences, the district councils showed the highest mean ranking as compared to city councils and municipal councils. An analysis of those variables which some significant variables between the three types of Local Authorities seemed to support the view that the district councils given the limited resources in terms of human capital and financial capital, perceived 
those obstacles as more serious when compared to the larger size of local authorities such as city councils and municipal councils.

\section{Summary and Conclusions}

Based on the discussion of the findings above, in terms of preparedness, the Local Authorities are well prepared to serve as a platform for the implementation of E-Government. This can be seen from the technology infrastructure, training and IT equipment being provided to the senior and middle management officers of Local Authorities.

In order for the Local Authorities to move towards the E-Government, more resources should be used in providing additional training facilities to fully maximize the infrastructure and IT equipment supplied to the senior and middle management officers. There seemed to be a gap in the necessary skills and knowledge of ICT as the number of officers both in the senior and middle management level who were given advanced ICT training is $27 \%$. Investments in such training would help to achieve the E-Government vision sooner rather than later.

In terms of methods of communication channels, the findings showed that there was still a high degree of reliance on the traditional methods. The traditional methods were seen as important methods in terms of knowledge transfer and knowledge sharing activities of local authorities. In order for the successful transformation towards E-Government, it is hoped that the electronic methods of communication channels would be used to complement the traditional methods.

Thus, increasing training efforts undertaken by Local Authorities in the process of maximum application of infrastructure and IT equipment provided would make the senior and middle management officers have greater confidence in the use of electronic medium of communication for the purpose of transfer and sharing of knowledge assets (explicit and tacit knowledge). An important aspect of the change process to E-Government is the awareness of the senior and middle management officers on the important role of KM in Local Authorities. Thus, this will smooth the way towards the change process involved in the transformation for E-Government environment.

It is without doubt that the findings of this survey showed that there is a high level of perceived importance of KM in Local Authorities with a mean score of more than 4.00. The perceived importance of KM is a crucial component towards achieving the objectives of E-Government. The obstacles towards ICT and $\mathrm{KM}$ as a suitable platform for E-Government could be overcome by increasing the financial and non-financial input into the smaller Local Authorities especially to district councils. Based on the above, we are confident in 
concluding that $\mathrm{KM}$ in Local Authorities is indeed a suitable platform for Local Authorities for the transformation towards E-Government.

\section{Limitation of the Study}

Due to time constraints, the researches are focused only on local authorities in Federal Territory of Kuala Lumpur and Selangor State and exclude other Local Authorities in other states of Malaysia.

\section{Suggestions for Future Research}

Research of KM and Local Authorities should also include all Local Authorities in Malaysia as this will add additional dimensions and perspectives in dealing with the issues of $\mathrm{KM}$ and E-Government in public sector organizations. It is also suggested that the perceived importance of $\mathrm{KM}$ as a suitable platform for E-Government in Local Authorities be obtained from the other important groups of people who are working directly at the forefront of government service delivery, such as Ministries, Federal and State government agencies.

\section{References}

Ahmad Sarji (1996). Civil Service Reforms Towards Malaysian's Vision 2020, Pelanduk Publication.

Ahmad Al-Athari and Mohamed Zairi (2001). Building Benchmarking Competence Through Knowledge Capability, Benchmarking : An Internal Journal, 8 (1), 70-80.

Davenport, T. H. et al. (1998). Successful Knowledge Management Projects. Sloan Management Review, Winter 98, 39 (2), 43-58.

Muhammad Rais Abdul Karim (1997). Reengineering the Public Service, Pelanduk Publications and MAMPU.

Ridderstrale, J. (2000). Business Moves Beyond Bureaucracy. Mastering Management. Financial Times, November 6.

Rory, L. Chase (1997). Knowledge Management Benchmarks, Journal of Knowledge Management, 1 (1), 83-92.

Ruggles, R. (1998). The State of the Nation : Knowledge Management in Practice. California Management Review, Spring. 
Sattar Bawany, Bawany Associates (2004). Implementation of Knowledge Management in Singapore Organizations, Journal of Knowledge Management Practice, October 2004.

Shields, R. Holden, T. and Schmidth, R.A. (2000). A Critical Analysis of Knowledge Management Initiatives in the Canadian Public Service : The Impact of a Knowledge - Based Economy on Work in the Public Service, the Virtual of Expertise and Knowledge - available at : www.carleton.ca/innovation $/ \mathrm{km}$ fed.pdf

Syed-lkhsan, S.O.S. and Rowland, F. (2004). Knowledge Management in a Public Organization : A Study on the Relationship Between Organizational Elements and the Performance of Knowledge Transfer, Journal of Knowledge Management, 8 (2), 95-111.

Syed-lkhsan, S.O.S. and Rowland, F. (2004). Knowledge Management in a Public Organization in Malaysia : Do People Really Share? KMICE 2004 seminar, UUM, Sintok, Kedah.

Wiiig, K.M. (1997). Knowledge Management : An Introduction and Perspective, Journal of Knowledge Management, I (1), 7-14.

Wiig, K.M. (2002). Knowledge Management in Public Administration, Journal of Knowledge Management, 6 (3), 224-239.

Zach, M.H. (1999a). Developing a Knowledge Strategy. California Management Review, Spring 99, 41 (3), 125-146. 